\title{
Peningkatan Kemampuan Pengolahan Data Melalui Pelatihan Statistik dan Aplikasi Program SPSS bagi Guru-Guru SMA di DIY
}

\author{
Tony Wijaya ${ }^{1^{*}}$ dan Nurhadi ${ }^{2}$ \\ ${ }^{1}$ Email: Tony@uny.ac.id \\ Universitas Negeri Yogyakarta \\ ${ }^{2}$ Email:Nurhadi.fe@uny.ac.id \\ Universitas Negeri Yogyakarta \\ *Correspondence: Email: Tony@uny.ac.id
}

\begin{abstract}
Abstrak. Selain memiliki tanggung jawab utama sebagai pendidik, guru juga memiliki peran dalam berkarya terutama dalam hal menulis. Melalui pengalaman penelitian, diharapkan guru mampu memahami kondisi lapangan dan mendesiminasikan temuannya dalam aktivitas belajar mengajar. Kemampuan menganalisis menggunakan statitsik beserta keahlian menggunakan program aplikasi statistik diharapkan mampu memotivasi dan meningkatkan kemampuan guru dalam riset. Kegiatan ini bertujuan meningkatkan pemahaman guru mengenai alat-alat statistik, mampu menentukan alat statistik secara tepat serta meningkatkan keahlian guru dalam mengoperasikan program statistik yang bermanfaat mendukung aktivitas penelitian. Metode aktivitas yang dilakukan adalah pelatihan statistik beserta program bagi guru-guru SMA di DIY. Guru diberikan materi dan didampingi untuk memahami alat-alat statistik serta program statistik dalam rangka meningkatkan kemampuan guru dalam melakukan pengolahan data. Hasil kegiatan menunjukkan adanya peningkatan kemampuan guru-guru SMA di Provinsi DIY dalam memahami alat-alat statistik dan kemampuan mengolah data mmenggunakan program statistik.
\end{abstract}

Kata Kunci: Data, Program, Statistik, Penelitian

DOI: $\underline{\text { http://dx.doi.org/10.35914/tomaega.v3i1.293 }}$

Article history:

Received January 11, 2020; Revised January 20, 2020; Accepted January 31, 2020

\section{PENDAHULUAN}

Koran Kedaulatan Rakyat tertanggal 14 Maret 2015 memberitakan bahwa minat guru untuk menyusun karya tulis ilmiah masih tergolong rendah, dan menunjukkan kesulitan yang dialami guru sebagai kendala dalam menulis karya ilmiah. Adapun hambatan yang dialami guru disebabkan oleh kesibukan oleh kegiatan sehari-hari di luar jam mengajar serta hambatan terkait kemampuan memahami alat-alat analisis, fungsi dan penggunaannya. Guru yang bergerak di bidang pendidikan memiliki peran yang penting, selain memberikan bahan ajar yang bersifat teoretis, guru juga harus mampu memberikan contoh berkarya terutama dalam hal menulis karya ilmiah. UU No.20 tahun 2003 mengenai sistem pendidikan nasional yang mengisyaratkan pentingnya kualitas pendidikan yang dipengaruhi oleh penyelenggaraan pendidikannya. Selain mengajar, tugas lainnya dari seoarng guru adalah menghasilkan suatu karya melalui kegiatan menulis. 
Guru diharapkan mampu memahami kondisi empiris di lapangan melalui kegiatan penelitian dan mendesiminasikan hasil dari kegiatan penelitian dalam proses belajar mengajar. Melalui pemahaman statistika dan fungsinya dalam analisis data beserta keterampilan mengoperasikan program statistik sebagai bagian alat bantu teknologi diharapkan mampu mendorong minat guru untuk melakukan penelitian. Ketrampilan teknologi memberikan manfaat bagi individu, sebagai contoh pelatihan yang diberikan oleh Suriyati (2019).

Statistik merupakan alat bantu dalam sebuah penelitian yang berorientasi pada paradigma kuantitatif. Statistik juga difungsikan sebagai alat yang membantu pengambilan suatu keputusan (Black, 2013). Analisis data dalam riset yang bersifat kuantitatif membutuhkan statistik sebagai teknik mengolah serta menganalisis data. Statistik memiliki fungsi sebagai teknik untuk menguji hipotesis dalam sebuah riset baik yang bersifat asosiatif maupun komparatif (Douglas et al., 2003). Fenomena statistik dalam penelitian sosial cenderung didominasi oleh penggunaan statistik yang berwujud asosiasi maupun komparasi, walaupun sebagian menggunakan statistik deskriptif (Wijaya, 2009; 2012).

Pelatihan statistik beserta program statistik diadakan dalam rangka memenuhi permintaan guru-guru SMA di DIY. Kegiatan pengabdian masyarakat ini juga di dukung oleh masukan atau saran yang berasal dari pserta dalam kegiatan-kegiatan pengabdian masyarakat sebelumnya. Berdasarkan observasi sebelumnya dari tim pengabdi juga ditemukan kesulitan yang dihadapi guru-guru terkait pengolahan data menggunakan alat-alat statistik beserta program aplikasinya.

Berdasarkan alasan-alasan tersebut di atas, maka menjadi bahan pertimbangan untuk diberikannya kegiatan pelatihan terkait statistik dan programnya bagi guru-guru. Dengan adanya keterbatasan waktu, dan tenaga, maka kegiatan pelatihan hanya dibatasi pada guruguru SMA yang berada di DIY serta kegiatan pelaihan ini difokuskan untuk meningkatkan kemampuan guru memahami konsep statistik secara tepat, mampu menggunakan teknik yang sesuai dalam menganalisis data serta memiliki kemampuan menggunakan program statistik khususnya program SPSS dalam analisis data penelitian. Dari hasil kegiatan ini, diharapkan bermanfaat bagi peserta pelatihan yaitu guru SMA di DIY agar lebih aktif dan produktif dalam aktivitas penelitian dan menghasilkan penelitian yang dapat didesiminasikan dalam proses belajar mengajar di kelas.

\section{METODE}

Metode kegiatan yang diadakan dalam pengabdian masyarakat ini berupa pelatihan. Tim pengabdi memberikan bimbingan para guru melalaui pelatihan guna meningkatkan kemampuan guru dalam mengolah dan menganalisis data sehingga menunjang kegiatan penelitian. Pelaksanaan pelatihan dilakukan secara bertahap. Tahap pertama, tim memberikan penjelasan tentang konsep-konsep statistik, tahap pelatihan ini berfokus pada konsep-konsep statistik, fungsi dan penggunaannya yang tepat sesuai permasalahan dalam penelitian. Tahap kedua, sesi pelatihan pada tahap ini memfokuskan pada kemampuan menggunakan program statistik. 
Metode teknis dalam pelatihan diberikan dengan cara metode ceramah mengenai penjelasan dasar tentang statistik, dalam pelatihan juga disertai dengan metode tanya jawab selama berlangsungnya pelatihan. Metode simulasi dipakai saat sesi praktik penggunaan program. Kegiatan pelatihan berlokasi di labolatorium komputer jurusan manajemen Fakultas Ekonomi UNY. Evaluasi kegiatan dilaksanakan selama pelatihan, baik di awal maupun akhir pelatihan guna mengevalusasi aspek capaian dari tujuan dilakukan pelatihan dan keberhasilan dari penyelenggaraan kegiatan. Evaluasi proses selama kegiatan dan capaian dari tujuan kegiatan menggunakan angket, serta observasi selama kegiatan. Keberhasilan pelaksanaan kegiatan pelatihan dapat dievaluasi melalui indikator 1) evaluasi sebelum dan selama pelatihan, dan 2) evaluasi setelah pelatihan.

\section{HASIL DAN PEMBAHASAN}

Pelatihan statistik dan aplikasinya dalam menggunakan program statistik bagi guruguru SMA di DIY dilaksanakan secara bertahap. Pelatihan diberikan dengan metode bersifat tatap muka. Kegiatan dilanjutkan dengan praktik dan simulasi mengoperasikan program SPSS. Kegiatan dilaksanakan pada tanggal 6-7 Oktober 2019 yang diikuti oleh 35 guru SMA di DIY. Kegiatan diawali dengan memberikan materi dan pembahasan mengenai statistik deskriptif, statistik asosiatif, statistik komparatif, statistik multivariat, pengenalan program SPSS, teknik analisis data menggunakan statistik deskriptif, asosiatif, komparatif dan multivariat.

Kegiatan dilaksanakan secara bertahap yang dibagi dalam beberapa sesi. Sesi pertama pelatihan diberikan secara tatap muka melalui ceramah mengenai konsep-konsep dasar statistika untuk penelitian, materi juga disertai dengan contoh-contoh riset yang berbasis kuantitatif. Kegiatan sesi ini diakhiri dengan sesi tanya jawab dan simulasi studi kasus statistik. Sesi pelatihan selanjutnya dilaksnakan pada hari selanjutnya yang dilanjutkan materi mengenai pengenalan program statistik SPSS, praktik mengoperasikan program SPSS, praktik pengujian instrumen penelitian, praktik analisis mengunakan statistik deskriptif, asosiatif dan komparatif. Berdasarkan observasi selama pelatihan, peserta mengikuti kegiatan pelatihan dengan antusias, hal ini ditunjukkan dengan keaktifan dari peserta untuk bertanya dan memberikan tanggapan atas pertanyaan maupun soal-soal latihan yang diberikan selama kegiatan pelatihan.

Hasil kegiatan pelatihan meliputi tercapainya tujuan dari kegiatan pelatihan, tersampaikannya materi pelatihan, kemampuan dari peserta dalam hal penguasaan materi serta adanya antusias dari peserta untuk mengajukan tawaran pelatihan di kemudian hari. Berdasarkan hasil evaluasi, kegiatan pelatihan terlaksana dengan baik, hal ini dapat ditunjukkan dengan indikator pemahaman peserta mengenai alat statistik dan ketepatan penggunaannya dalam menyelesaikan permasalahan penelitian selama pelatihan, dan peserta mampu mengolah maupun menganalisis data yang dapat dilihat dari lembar hasil latihan.

Penilaian pada materi yang diberikan juga termasuk baik yang dapat dilihat dari hasil lembar evaluasi proses pelatihan, sebagian besar peserta dapat memahami materi dengan baik, hal ini didukung pengamatan dari tim pelaksana kegiatan saat pelatihan berlangsung. 
Peserta mampu menguasai materi dengan baik yang ditunjukkan dengan hasil penyelesaian tugas yang diberikan selama pelatihan. Peserta juga mampu menanggapi maupun memberikan jawaban yang tepat atas pertanyaan-pertanyaan stimulan yang diberikan oleh pelaksana pelatihan. Peserta secara menyeluruh puas dengan kegiatan pelatihan dan merasa terbantu dengan adanya kegiatan pelatihan ini sebagai upaya meningkatkan kompetensi peserta dalam melakukan penelitian.

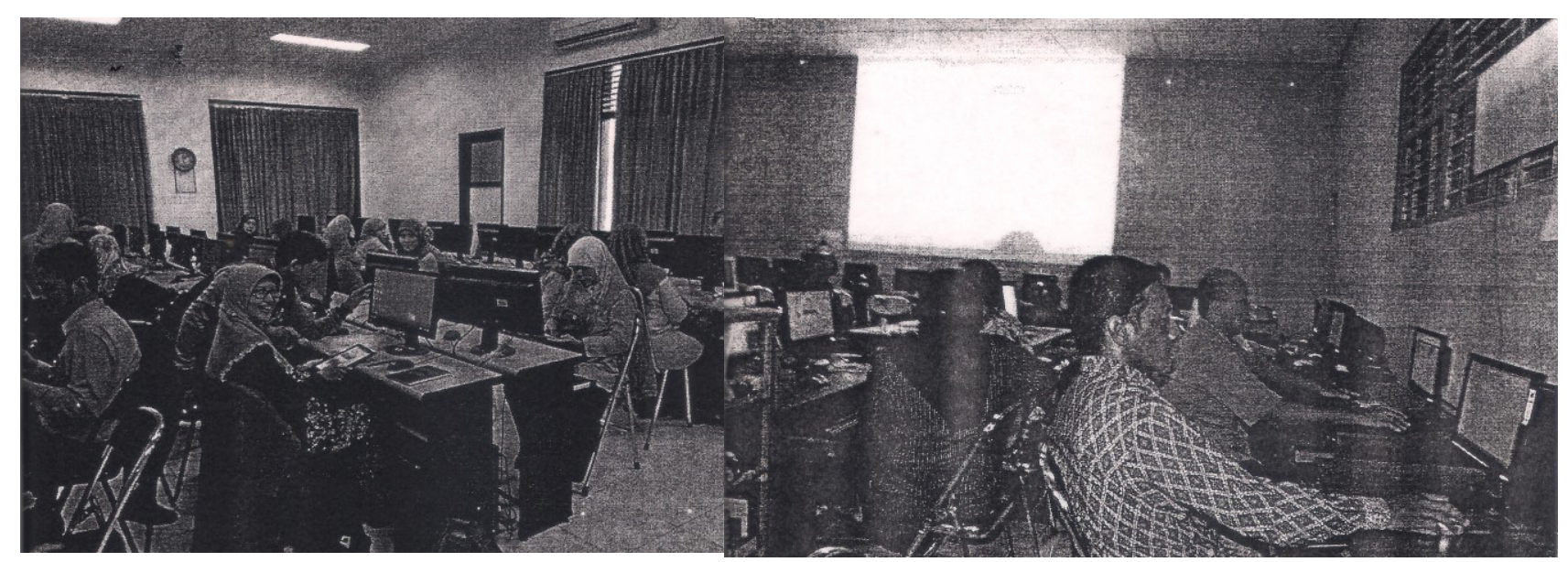

Gambar 1. Kegiatan Pelatihan

\section{SIMPULAN DAN SARAN}

Kegiatan pelatihan statistik dan program statistik yang diberikan kepada guru-guru SMA di DIY terlaksana dengan baik. Peserta mampu menerima materi dengan baik. Peserta aktif selama mengikuti proses kegiatan pelatihan dan memiliki antisius yang tinggi selama pelatihan. Ketercapaian hasil ditunjukkan oleh hasil lembar evaluasi yang menunjukkan bahwa sebagian besar peserta memahami dengan baik materi yang disampaikan oleh tim pelaksana. Kegiatan yang terlaksana dengan baik juga didukung dengan hasil observasi selama kegiatan pelatihan. Secara menyeluruh hasil menunjukkan sebagai berikut:

1. Meningkatnya kemampuan kemampuan pemahaman alat-alat statistik serta fungsinya bagi guru-guru SMA di Provinsi DIY

2. Meningkatnya kemampuan guru-guru SMA di DIY dalam mengolah data menggunakan program statistik

Berdasarkan hasil lembar evaluasi dari kegiatan pelatihan yang sudah terlaksana dengan baik dapat diberikan saran berupa kelanjutan dari kegiatan ini. Kegiatan selanjutnya dapat diusulkan dengan kegiatan pelatihan materi lanjutan yang tidak terbatas hanya pada analisis data namun pendampingan penyusunan artikel penelitian untuk publikasi.

\section{DAFTAR PUSTAKA}

Black, K. (2013). Business Statistics, John Willey \& Sons

Douglas, L., Marchal, W., \& Wathen, S. (2003). Basic Statistics For Business and Economics, McGraw Hill 
TOMAEGA Vol. 3, No. 1, Februari 2020, hlm: 31-33

Juknis Pelaksanaan Angka Kredit Bagi Jabatan Guru, dikutip dari Kepmendikbud No.02/O/1995: 44-45

Suriyati. (2019). Desain Perancangan E-Commerce Kain Tenun Lombok Desa Sukarara Lombok Tengah. To Maega. Vol 2 No 2. Pp. 36-43

UU nomor 20 tahun 2003 tentang Sistem Pendidikan Nasional. Yogyakarta: Pustaka Pelajar Wijaya, T. (2009). Analisis Data Penelitian. Yogyakarta: Cahaya Atma.

Wijaya, T. (2012). Cepat menguasai SPSS. Yogyakarta: Cahaya Atma. 